IZA DP No. 7501

Low-Skilled Immigration and Parenting Investments of College-Educated Mothers in the United States: Evidence from Time-Use Data

Catalina Amuedo-Dorantes

Almudena Sevilla Sanz

July 2013 


\title{
Low-Skilled Immigration and Parenting Investments of College-Educated Mothers in the United States: Evidence from Time-Use Data
}

\author{
Catalina Amuedo-Dorantes \\ San Diego State University \\ and IZA
Almudena Sevilla Sanz
Queen Mary University of London
and IZA

Discussion Paper No. 7501

July 2013

IZA

P.O. Box 7240

53072 Bonn

Germany

Phone: +49-228-3894-0

Fax: +49-228-3894-180

E-mail: iza@iza.org

\begin{abstract}
Any opinions expressed here are those of the author(s) and not those of IZA. Research published in this series may include views on policy, but the institute itself takes no institutional policy positions. The IZA research network is committed to the IZA Guiding Principles of Research Integrity.

The Institute for the Study of Labor (IZA) in Bonn is a local and virtual international research center and a place of communication between science, politics and business. IZA is an independent nonprofit organization supported by Deutsche Post Foundation. The center is associated with the University of Bonn and offers a stimulating research environment through its international network, workshops and conferences, data service, project support, research visits and doctoral program. IZA engages in (i) original and internationally competitive research in all fields of labor economics, (ii) development of policy concepts, and (iii) dissemination of research results and concepts to the interested public.
\end{abstract}

IZA Discussion Papers often represent preliminary work and are circulated to encourage discussion. Citation of such a paper should account for its provisional character. A revised version may be available directly from the author. 
IZA Discussion Paper No. 7501

July 2013

\section{ABSTRACT}

\section{Low-Skilled Immigration and Parenting Investments of College-Educated Mothers in the United States: Evidence from Time-Use Data}

This paper uses several decades of US time-diary surveys to assess the impact of low-skilled immigration, through lower prices for commercial child care, on parental time investments. Using an instrumental variables approach that accounts for the endogenous location of immigrants, we find that low-skilled immigration to the United States has contributed to substantial reductions in the time allocated to basic child care by college-educated mothers of non-school age children. However, these mothers have not reduced the time allocated to more stimulating educational and recreational activities with their children. Understanding the factors driving parental time investments on children is crucial from a child development perspective.

JEL Classification: J01, J13, J61

Keywords: migration, time use, mother

Corresponding author:

Almudena Sevilla Sanz

Queen Mary University of London

School of Business and Management

Francis Bancroft Building

Mile End Road

London E1 4NS

United Kingdom

E-mail: A.Sevilla@qmul.ac.uk 


\section{The most valuable of all capital is that invested in human beings; and of that capital the most precious part is the result of the care and influence of the mother.}

\section{Alfred Marshall (1890), Paragraph VI.IV.11.}

\section{Introduction}

This paper examines how low-skilled immigration, via its effect on the cost of household services, may have impacted the allocation of time to child care of mothers in the United States. Child care is an important component of parental time. Unlike other types of home production, such as cleaning the house windows or maintaining a tidy home, child care, and some types of child care in particular (such as educational and recreational child care), can prove particularly important for a child's posterior intellectual and social development (e.g. Hill and Stafford 1974, Leibowitz 1974, Del Boca et al. 2010). Given the importance of intergenerational transmission of human capital in explaining children's life outcomes, understanding the factors driving parental time investments on children and how their impact varies according to the educational attainment of mothers is crucial from a child development perspective and for policy-making aimed at reducing inequality.

A few papers show how large increases in low-skilled immigration over the past decades (in excess of 40 percent for the 1970-2000 time period) allowed for a substantial reduction in the price of locally-traded goods and services that are immigrant-intensive in the United States. For instance, Cortés (2008) shows that the low-skilled immigration wave of the 1980-2000 resulted in an important reduction in the price of an agglomerate of non-traded goods and services by a city average of 9-11 percent. Immigrants are overrepresented in the child care sector and immigrants employed in child care are excessively low-skilled, as noted by Blau (2003) and Helburn and Howes (1996). ${ }^{1}$ Furtado and Hock (2009) find that the lowskilled immigration wave of the 1980-2000 in the United States contributed to lower cost and increased availability of child care services. In particular, it led to a 13.5 percent reduction in the median wage of workers employed in those services -the wage bill accounting for 60 to 80 percent of the operating expenses at formal and home-based childcare centers (Helburn and Howes 1996, Blau and Mocan 2002) and possibly more in informal childcare providers. More importantly, the increase in low-skilled immigration between 1980 and 2000 also reduced the wages of childcare workers at the 75th percentile by 9 percent. As such, the

\footnotetext{
${ }^{1}$ Blau (2003) further notes that child care is one of the easiest occupations to enter. Regulations concerning the qualifications of child care workers are inexistent at the federal level. At the state level, the regulations are often minimal and, in those states where they are tougher, the vast majority of child care is unlicensed. Furtado and Hock (2009) report that in the year 2000, low-skilled immigrants with no post-secondary education represented $9.3 \%$ of child care workers, versus $6.2 \%$ of the workforce in the non-household services occupations.
} 
impact of low-skilled immigration was not only felt among child care workers employed in what we might think of as low-quality child care centers less likely to be servicing highskilled mothers, but also among child care workers in the higher income spectrum potentially servicing highly-educated parents. ${ }^{2}$ This is expected if, as noted by Blau and Currie (2004), the alternative to high quality child care is not home care but, rather, lower quality child care. In that case, lower quality child care ends up serving as a substitute to higher quality child care and reductions in the price of low quality child care will impact the demand for high quality child care and, ultimately, its price.

Using a time use model in the tradition of Becker (1965) and Gronau (1977), we show that lower prices for domestic services brought about by an increase in low-skilled immigration may have induced some mothers able to afford commercial child care services to reduce the time allocated to providing child care with a close market substitute, as is often the case with basic child care consisting of bathing, feeding, or changing diapers. Owing to their ability to finance market-provided child care services and the higher opportunity cost of their time, the aforementioned effect is more likely to take place among high-skilled or collegeeducated mothers.

We test these hypotheses using historical time use data from the American Heritage Time Use Surveys (AHTUS), which expand from the 1970's to the first decade of the 21st century. The main instrument of all the surveys is an activity diary in which respondents record what they do for a consecutive period of 24 hours, which provides a high quality measure of time dedicated to child care activities. To identify a casual effect of low-skilled immigration on maternal time investments in children, we instrument for low-skilled immigrant concentration using information on the historical distribution of immigrants of a particular country as a predictor of current immigrant location choices (Card 2001).

We find that increases in low-skilled immigration to the United States lowered the time allocated to basic child care activities (as well as to home production) by native mothers with more than a high school degree by approximately half an hour per week. These findings suggest that child care services provided by low-skilled immigrants may serve as a good substitute for basic maternal child care and routine housework activities, but not for other types of child care activities involving English proficiency or a certain level of human capital,

\footnotetext{
${ }^{2}$ As noted by Hotz and Kilburn (1991), Blau and Hagy (1998) and Blau and Currie (2004), high-income women may demand a better quality of care. If low-skilled immigrants are more likely to be employed in low-quality child care centers, one might be concerned that the influx did not impact the price of child care to be paid by highly-educated mothers.
} 
such as reading. We further show that these effects are unique to college-educated mothers with non-school age children.

This paper adds in important ways to three different strands of literature. First, it contributes to the literature on the impact of low-skilled immigration. Most of the earlier literature examined the potential negative impact of low-skilled immigration on the employment and wages of natives (Card 2001, Borjas 2003). More recently, the interest has shifted to the positive potential effects of immigration on the cost of household services (Cortés 2008, Furtado and Hock 2009) and on labor supply and fertility (Cortés and Tessada 2010, Furtado and Hock 2010, Farré et al. 2011). In this paper, we examine for the first time its impact on parenting investments. Our findings complement those from Cortés and Tessada (2010), who using a different data source find that low-skilled immigration to the United States increased the hours worked and reduced the time dedicated to housework of women with a professional degree or Ph.D. Likewise, we provide empirical evidence of one of the channels by which low-skilled immigration has reduced the work-fertility tradeoff facing educated women in the United States as argued by Furtado and Hock (2010) -namely through the reduction of some types of child care and the time dedicated to home production.

Second, we also contribute to a recent but growing literature exploring the impact of child care utilization on the resources received by children and, in particular, on the time and type of parental care. This is important because, as pointed out by Baker et al. (2008), in order to evaluate how child care subsidies affect child development, we must look at whether the substitution of parental care for commercial child care results in an increase or decrease in the net resources received by children. However, these studies lack information on the time or the type of parental care. We fill this gap in the literature by providing direct evidence of the kind of trade-offs that college-educated mothers face in terms of their use of time. Particularly, we find that following a reduction in the price of market child care services triggered by an increase in low-skilled immigration, these mothers reduce the time invested in basic child care activities, but not the time allocated to more stimulating educational and recreational activities with their children. Nevertheless, their overall child care time decreases.

Lastly, our findings inform about the mediating role that low-skilled immigration may have had on the trends in the educational gradient in parental time. A series of papers have recently documented that more educated women devote more time to child care activities than low educated women (Sayer et al. 2004, Guryan et al. 2008) and that this differential has increased over time in the United States (Ramey and Ramey 2009). The mechanisms behind 
these secular patterns are, however, still not well-understood. We find that low-skilled immigration inflows may have helped counteract the diverging patterns in basic child care time among native mothers with different skills.

The paper is organized as follows. Section 2 describes the theoretical framework from which we derive some testable hypotheses regarding the impact of low-skilled immigration on the child care patterns of mothers in the United States. Section 3 and Section 4 describe the data and inform on some trends in time use, respectively. Section 5 discusses the methodology and Section 6 presents the findings. Finally, Section 7 summarizes our results and concludes the paper.

\section{Theoretical Framework}

We rely on a simple time-use model in the tradition of Becker (1965) and Gronau (1977), according to which a mother allocates her time to three competing time uses: market work, leisure, and child care. The main purpose of the model is to explain the differential impact that low-skilled immigration may have on mothers' child care provision depending on their educational attainment and the type of child care at hand. We assume that mothers derive utility from well-cared-for children $(c)$ and leisure $(l):^{3}$

$$
U=U(c)+V(l)
$$

where $U$ and $V$ are concave and increasing utility functions in $c$ and $l$ respectively.

Well-cared-for children contribute to maternal utility in various ways. For example, children may increase the enjoyment that mothers derive from spending time with their children. Alternatively, well-cared-for children may increase maternal utility through other venues noted in the literature. For instance, mothers may altruistically care about their children and consider time with their children as an investment in their children's human capital. Parents may also care selfishly about their children's future earnings potential; perhaps hoping that they may be able to help them out at an older age (Guryan et al. 2008). More important to us is the fact that well-cared-for children require parental time and/or the use of market-provided child care services. We can formalize this idea using a production function for well-cared-for children that calls for the use of market-provided child care services $(x)$ and parental time $(h)$ :

$$
c=c(x, h)
$$

where $c$ takes the usual form of an increasing and concave function of $x$ and $h$.

\footnotetext{
${ }^{3}$ For a specific functional form, see Aguiar and Hurst (2007). The model can be easily extended to include other forms of home production, leisure, and consumption goods.
} 
Mothers maximize the utility function in equation (1) subject to the production function in equation (2), as well as time and budget constraints. Specifically, they have a total time endowment of 1 that they can use in the labor market $(L)$, taking care of children (h), and/or leisure (l). They also face the following budget constraint: $p x=w(1-h-l)$, where $w$ is the market wage and $p$ is the cost of market-provided child care services.

For an interior solution (i.e., as long as $x>0$ ), the first order conditions yield the following relationship:

$$
\frac{c_{h}^{\prime}}{c_{x}^{\prime}}=\frac{w}{p} \quad \text { for } w \geq \bar{w}(3)
$$

Equation (3) states that the marginal rate of substitution between parental child care time $(h)$ and commercial child care $(x)$ must equal their relative prices. ${ }^{4}$

The first prediction of the model is that the degree to which the demand for marketprovided child care rises with low-skilled immigration depends on the degree to which maternal and commercial child care are substitutable. In terms of Equation (3) this prediction implies that, for the same reduction of maternal child care time, mothers will need to be compensated with a bigger decrease in the price of those market child care services $(p)$ with few substitutes in the market. The degree to which maternal and commercial child care can be considered substitutes depends on the kind of child care in question. Low-skilled immigrant child care workers may be in a better position to provide basic child care consisting of changing diapers, bathing, dressing up and feeding children rather than to provide educational or recreational child care involving reading in English or taking the child to activities with other English-speaking children and parents. Therefore, an increase in lowskilled immigration is expected to alter the maternal provision of basic child care to a greater extent than the provision of other forms of child care. Under certain conditions (for example, if maternal basic and educational child care are substitutes), maternal educational and recreational childcare may increase as mothers free up their time from basic child care activities.

\footnotetext{
${ }^{4}$ In this simple set up, changes in the cost of child care services do not affect the consumption of leisure since we have assumed separability between leisure $(l)$ and well-cared-for children $(c)$ in the utility function. Therefore, if maternal child care time $(h)$ drops among college-educated mothers as low-skilled immigration rises, the time constraint dictates that the labor supply $(L)$ of those mothers should rise with low-skilled immigration. Nevertheless, one could relax the assumption of separability between leisure and well-cared-for children in the utility function, in which case the extent to which leisure would change would depend on the degree of substitution between leisure and well-cared-for children. If, for example, leisure and well-cared-for children are complements, e.g. better cared-for children require more leisure time spent with them, leisure may increase as the cost of raising well-cared-for children drops, and labor supply might not increase as much. Therefore, the extent to which leisure and labor supply change remains an empirical question.
} 
The second prediction from this simple model is that a decline in the price of child care services ( $p$ ) brought about by an increase in low-skilled immigration raises the demand of commercial child care services ( $x$ ) and reduces maternal time (h) among college-educated mothers as long as $h$ and $x$ are substitutes in the production of children. This prediction follows from the fact that, as noted by Cortés and Tessada (2010) for household production services, commercial child care services $(x)$ are only used by women with a wage $(w \geq \bar{w})$ that is high enough relative to the cost of market-provided child care services $(p) .{ }^{5}$ These women are more likely high-skilled or college-educated mothers; therefore, equation (3) only applies to them. A lower $p$ is also expected to make market-provided child care services affordable to some mothers who previously were unable to pay for it. However, once again, college-educated mothers with lower wages (perhaps they were starting their careers) that are, nevertheless, closer to the required threshold $\bar{w}$ to purchase commercial child care services are more likely to fall within that group. Overall then, via the aforementioned channels, an increase in low-skilled immigration is expected to reduce the time allocated to basic child care by college-educated mothers. ${ }^{6}$

From a theoretical point of view, the predicted impact of low-skilled immigration on the time allocated to childcare by college-educated fathers should be identical to the impact experienced by mothers. As the market price of child care drops, both mothers and fathers should reduce the time they spend in basic child care activities easily performed by lowskilled immigrant workers employed as nannies. Thus, we also run the analysis for fathers married to college-educated native mothers as a sensitivity analysis. However, we follow the literature on time uses in home production (e.g. Cortes and Tessada (2010) for housework time) and focus our main analysis on the childcare provision of mothers for two reasons. First, mothers dedicate four times as much time to child care than fathers. In fact, only one fourth of fathers report ever doing any child care during a regular diary day. Second, it is not clear that fathers' educational attainment is the one that matters the most in the provision of childcare (e.g. Breierova and Duflo 2004, Schultz 2002).

\section{Data}

We use the American Heritage Time Use Study (AHTUS), a harmonized dataset that covers five decades and over five time use surveys running from 1965 to 2003. Table B1 in

\footnotetext{
${ }^{5}$ See case no. 2 in Appendix A to see the relative magnitude of the relative wage threshold $\bar{w}$.

${ }^{6}$ As in Cortes and Tessada (2010), within the group of mothers who are already purchasing commercial child care services, those with lower salaries will reduce their own child care provision by more than those with higher salaries when the cost of market-provided child care services $(p)$ falls.
} 
Appendix B describes the five surveys in the AHTUS as well as the harmonization exercise. The main instrument of all the surveys is an activity diary in which respondents record what they do for a consecutive 24-hour period. Each day of the week is equally represented in the survey. The methodological literature (e.g. Robinson and Juster 1985, Juster 1985) shows that diary estimates of time spent on different domestic activities provided by time surveys are more accurate than responses to questionnaire items. ${ }^{7}$ Similarly to retrospective questions on expenditure, time use information gathered this way runs into recall problems, which are accentuated due to the limited arithmetic facility and the difficulty of individuals to assess the appropriate reference period limits. Thus, the same way money expenditure diaries have become the gold standard in the consumption literature, so have time-use diaries become the preferred method to gather information on time spent on market work, nonmarket work and leisure. Most studies documenting long term trends in how individuals use their time are now based on these data sets, including recent studies for the analysis of trends in time use and in child care (e.g. Guryan et al. 2008, Aguiar and Hurst 2007, Bianchi et al. 2006, Robinson and Godbey 1999).

Our primary sample of analysis includes observations from the AHTUS survey years 1975-76, 1992-94, and 2003. We do not include respondents from the 1965-66 AHTUS since it is too close to the year our instrument refers to (i.e. 1960). Additionally, we are unable to use the 1985-86 AHTUS because it does not contain any information on the state of residence of the respondent, which is crucial for our identification strategy. Overall, our sample consists of 3,740 women. Because the 2003 data are from the first year of the American Time Use Survey, it represents 75 per cent of the overall sample (2,822 women). Sample sizes for earlier surveys are smaller (482 women in the 1970 AHTUS data and 436 women in the 1990 AHTUS data). Following the literature, we use the AHTUS weights to provide a representative picture of the population at hand (Aguiar and Hurst 2007).

Mothers between 21 and 55 years of age who have completed a 24-hour time diary are our group of interest. Following previous work by Furtado and Hock (2010), we focus our attention on non-Hispanic mothers. As noted by these authors, the restriction addresses important differences in social norms and peer effects when it comes to childrearing. More importantly for us is the fact that it allows us to obtain a closer estimate of what the impact of low-skilled immigration might have been on the child care practices of non-immigrant

\footnotetext{
${ }^{7}$ For example, in a recent experiment, Hiddle et al. (2010) determined the reliability and validity of time use data over more traditional self-report surveillance systems for assessing sedentary and physical activity behavior by successfully matching the results from the diary to those from an accelerometer.
} 
mothers given that the AHTUS lacks information on the individual's immigrant status and the bulk of low-skilled immigrants came from Latin America. Additionally, since the channel by which low-skilled immigration may be impacting the provision of child care by mothers is through the reduction in the cost of commercial child care services, we pay special attention to mothers of non-school age children. After all, enrollment in public school, which starts at six years of age, may be thought of as inexpensive child supervision (Gelbach 2002). We also perform various robustness checks, including high-skilled mothers of older children and high-skilled fathers. Our main conclusions close the paper.

Our variable of interest is the time mothers report spending on child care. Many of the tasks constituting child care can be purchased in the market, and so economists often include child care as another form of housework (e.g. Burda et al. 2008). Parents, however, report that spending time with their children is among their more enjoyable activities together with leisure activities, especially when compared with other standard home production activities (e.g. Juster 1985, Robinson and Godbey 1999, Guryan et al. 2008, Krueger et al. 2009). As a result, in sharp contrast with the negative education and income gradient researchers have observed for the amount of time allocated to home production and leisure (e.g. Robinson and Godbey 1999, Aguiar and Hurst 2007), child care appears to rise with education and income (e.g. Hill and Stafford 1974, Sayer et al. 2004, Kimmel and Connelly 2007, Guryan et al. 2008). In sum, parents view time caring for children as fundamentally different from either home production or leisure and more like an investment.

We follow the usual practice in the time use literature and conceptualize time investment in children as the total time during which any form of child care is reported by the respondent as the primary activity during the designated day. Primary child care activities, however, cannot be equalized with time that parents spend with children. Indeed, there is some evidence that child care reported as the primary activity significantly underreports total child care time (e.g. Budig and Folbre 2004, Folbre and Bittman 2004, Bianchi et al. 2006). As pointed out in Folbre and Yoon (2007), humans are multitasking beings whose activities often elude clear categorization. Two other ways to measure child care in time diary surveys is to look at the so-called secondary activity and at the information on who else is present when the activity takes place. In particular, for each primary activity, the respondent is asked a question about "what else" he or she is doing. This so-called secondary activity often includes child care. Respondents are also asked who the activity is done with. Multiple individuals could be listed, including a child. Unfortunately, information on secondary activities or complementary information on who else is present while the activity is taking 
place is not perfectly comparable across the AHTUS surveys and is entirely missing for the 1990s, with no secondary information for the 2000s survey. Nevertheless, because primary child care time requires direct interaction with the child, it is important in itself as it is considered to be the most stimulating for children (see Guryan et al. 2008). ${ }^{8}$

Inspired by the classification used in Aguiar and Hurst (2007), we distinguish two broad types of child care within primary child care: basic child care and educational/recreational child care. The former includes the physical care of children (bathing, dressing, feeding, changing diapers), organizing and planning for children and, overall, looking after children. The latter includes activities such as reading to children, teaching children, attending meetings at a child's school, playing games with children, playing outdoors with children, attending a child's sporting event or dance recital, going to the zoo with children, and taking walks with children. ${ }^{9}$

Aguiar and Hurst (2007) note that there is some ambiguity about whether child care is treated consistently across all surveys. Robinson and Godbey (1999) raise several concerns about the comparability of 1993 child care measures to the measures of child care in the other surveys. Egerton et al. (2006) also caution against making comparisons between the 1993 and 2003 time-use surveys. To allow for more meaningful comparisons, we focus on two broad classification of child care activities, i.e. basic and educational/recreational child care. Doing so allows us to avoid biases from changes in the classification of time-use activities over time (with some activities disappearing and new activities emerging- just as in the case of expenditure diary categories in expenditure surveys). Yet, as Aguiar and Hurst (2007) point out, to the extent that low and highly educated individuals are affected by data collection methods in the same way, the differential impact that low-skilled immigration might have on child care according to maternal educational attainment in any given year should remain unaffected. We further include survey fixed-effects in the regression analysis to address any changes in survey methodologies.

\footnotetext{
${ }^{8}$ In contrast to time spent with children reported as primary activity in the diary, Guryan et al. (2008) use the most recent American Time Use Survey (ATUS) and find that total time spent in the company of a child is the same for low and highly educated mothers. This finding is interpreted by the authors as suggestive that highlyeducated parents view child care as an investment in which it is important to devote their active attention.

9 Specifically, basic child care includes the following categories in the AHTUS files: $33=$ care of infants, 34=general care of older children, 35=medical care of children and 39=other child care. Educational and recreational child care includes the following categories in the AHTUS files: 36=play with children, $37=$ supervise child or help with homework and 38=read to, talk with the child. We exclude travel time related to child care activities from our child care definitions as we lack information on whether the latter is associated to a so-called basic or recreational/educational child care activity. However, our key findings are robust to its inclusion among basic or recreational/educational child care activities (results available upon request).
} 


\section{Some Descriptive Statistics on Child Care Trends}

Table 1 displays the trends in child care practices of mothers with children under the age of 6 during the past three decades by mother's educational attainment. We separate basic from educational and recreational child care and distinguish by mothers' educational attainment. In addition, to provide us with a full picture of these women's time uses, Table 1 displays the time dedicated by our sample of mothers to market work, housework, and any other activities -henceforth: residual time. ${ }^{10}$ And, as it is commonly done in the literature, we compare mothers with more than a High School degree -to whom we refer to as "collegeeducated mothers” as they have, at the minimum, some college education- to mothers with, at most, a High School degree.

A few findings are worth discussing. First of all, college-educated mothers spent more time than their less educated counterparts in both basic and educational or recreational child care throughout the time period under examination. Secondly, while all mothers increased the time allocated to both types of child care, the increase in educational and recreational child care was especially large among college-educated mothers. Among them, educational and recreational child care rose by 338 percent -from 1.6 hours/week to 7 hours/week, as opposed to the 241 percent increase experienced by their less educated counterparts. In contrast, less educated mothers increased the time dedicated to basic child care by 42 percent, whereas their college-educated counterparts raised it by approximately 26 percent.

In addition to the increase in childcare time, the figures in Table 1 reveal the wellknown increase in time devoted to market work and the reductions in time allocated to home production. While both college-educated mothers and their counterparts with at most a high school education cut down the time invested in home production by similar amounts, less educated mothers experienced much larger increases in the time allocated to market work (which increased by 58 percent as opposed to 29 percent for more educated mothers). Still, less educated mothers continued to work, on average, less time than their more educated counterparts.

In sum, the time allocated to both types of child care significantly rose over the time period under analysis for all mothers. Nevertheless, the increase in educational/recreational child care was particularly noticeable -even more so among college-educated mothers. In what follows, we explore the role that immigration, through its effect on lowering the price of

\footnotetext{
${ }^{10}$ We group within the category of "residual time" all other time uses -such as leisure, volunteering, civic activities, exercises, hobbies and overall personal care.
} 
domestic services, may have had in shaping the time allocated to different types of child care according to mothers' educational attainment.

\section{Methodology}

\subsection{Model Specification and Testable Hypotheses}

We are interested in examining the impact that low-skilled immigration, through its reduction of the price of household services, has had on the child care time allocation of mothers of non-school age children in the United States. Because we lack detailed information on the price of household services for the time period under analysis at a disaggregate level, we follow the literature and estimate a reduced-form equation where the main explanatory variable is the share of low-skilled immigrants at the region-decade level. As mentioned in the Introduction, the justification for this analysis stems from the already existing evidence on how low-skilled immigration reduced the price of non-traded goods and, in particular, domestic and child care services in the United States (e.g. Cortés 2008, Furtado and Hock 2009). These authors show that a higher share of low-skilled workers and, in particular, immigrant workers, lowered the price of domestic services, including child care, and increased its availability. ${ }^{11}$ Lower prices and higher availability of market-provided child care services should, in turn, induce mothers to purchase those services and reduce their child care time, other things equal. We thus look at how low-skilled immigration may be impacting the time allocated to different types of child care by mothers' education in the United States via its demonstrated impact on the price of domestic services. We model the impact of low-skilled immigration on the time dedicated by college-educated mothers of nonschool age children to child care by:

$$
C C_{i s t}=\alpha_{i s t}+\beta * \text { Share }_{s t}+X_{i s t}^{\prime} \chi+\phi_{s}+\varphi_{t}+\varepsilon_{i s t}
$$

where $i$ stands for the individual woman, $s$ indicates the state of residence, and $t$ the time (in our case decade) to which the observation refers to. $C C_{i s t}$ stands for the type of child care

\footnotetext{
${ }^{11}$ Although our unit of analysis differs from that of Furtado and Hock (2009), who focus on large metro areas as opposed to states, we first confirm the negative impact of an increase in low-skilled immigration on the wages of child care workers over the time period under consideration. We do so by regressing the log median hourly wages of child care workers in state $s$ and year $t$ on the share of low-skilled immigrant workers in the labor force in state $s$ and time $t$. Results are shown in Table B2 in the appendix. Given the semi-log specification of the wage regression, the estimated coefficient represents the percentage change in the wages of child care workers caused by a one percentage point increase in the share of low-skilled immigrants. During the period under examination, the low-skilled immigrant share rose from 4.2 percent in 1970 to about 6.1 in 2000. We estimate the model via ordinary least squares (OLS) as well as using instrumental variable (IV) methods to account for the endogeneity of the share of low-skilled immigrants. Based on the IV estimates, for which we use the same instrument we employ in estimating equation (1) above, this increase lowered the median wage of child care workers by approximately 7 percent.
} 
time at hand. The vector $X_{\text {ist }}$ contains individual level information, such as age, a dummy variable for whether the respondent is white, the number of adults living in the household, the number of children under the age of 6 , the age of the youngest child, and dummy variables indicative of whether the time use referred to a week day and whether the diary was collected during the summer months. ${ }^{12}$ The vectors $\phi_{s}$ and $\varphi_{t}$ refer to the state and time (or survey) fixed-effects, respectively. We allow the disturbance term to be correlated across individuals (and over time) in the same state.

Our key regressor is the variable Share $_{\text {st }}$, which stands for the share of low-skilled (i.e. non-college educated with at most a High School diploma) immigrant workers in the labor force in state $s$ and time $t$. As such, the estimated coefficient $\beta$ informs about the impact that an increase in the share of low-skilled immigrant workers has on the child care patterns of college-educated women. As shown in the first row of Table 2, this share, which we construct using Census data to minimize any attenuation biases, ${ }^{13}$ increased from an average of 4.2 percent in 1970 to almost 6.1 percent by the year 2000 . The first three columns of Table 2 also reveal the state-level variability in the share of low-skilled immigration over the time period under consideration. For instance, while California displays the largest share of low-skilled immigrants by the year 2000 (followed by New York and Florida), it is not among the three states experiencing the major growth spurs in lowskilled immigration between the 1970s and the 2000s. Rather, states like Georgia, North Carolina and Texas witnessed increases in low-skilled immigration of over 200 percent (in Georgia and North Carolina these increases were above 700 percent), whereas some large immigrant states, like New York, did not experience a significant change in their low-skilled immigrant shares. Finally, some states, like Maine, Massachusetts, Michigan, Ohio or Pennsylvania, saw their share of low-skilled immigrants fall.

The last three columns of Table 2 also display alike figures for the share of lowskilled female immigrants -an alternative share used in the main analysis as a robustness check on the basis that the vast majority of low-skilled immigrants employed in child care are likely to be female. Percentage wise, the average increase in this share over the time period under consideration is rather similar to the one displayed by the share of low-skilled immigrants (i.e. in the order of 45 percent). Likewise, Georgia, North Carolina and Texas are

\footnotetext{
12 Table B3 in Appendix B contains the means and standard deviation for these regressors.

${ }^{13}$ As noted by Aydemir and Borjas (2006), measurement error in a key regressor (e.g. share of immigrants) in analyses relying in a spatial correlations approach are likely to result in a significant attenuation bias. Therefore, instead of using the AHTUS data, we rely on the Census to construct our share.
} 
the three states experiencing the largest increase in that share between the 1970s and the 2000s.

As noted earlier in the discussion of our model, not all child care services are good substitutes for parental child care. Time spent reading a book might not be easily substitutable, even more so if low-skilled immigrant nannies are not proficient in English. As such, some college-educated mothers might take advantage of cheaper child care services and reduce the time they spend on basic child care, but not the time spent on educational and recreational activities. Thus, we estimate equation (1) separately for each type of child care.

Likewise, we estimate equation (1) separately for mothers with up to a High School degree and college-educated mothers with more than High School degree. As previously discussed, the impact of a low-skilled immigrant shock is likely to vary with mothers' educational attainment. A higher share of low-skilled immigrant workers may actually reduce the employment opportunities available to less educated mothers and, consequently, the opportunity cost of taking care of their own children. Hence, the coefficient $\beta$ may be either positive or non-statistically different zero for that group of mothers. In contrast, a higher share of low-skilled immigrant workers (more likely to be complementary to highskilled labor) may actually increase the employment opportunities available to collegeeducated mothers and, in turn, the opportunity cost of staying home taking care of non-school age children. Furthermore, these mothers are more likely to be able to afford marketprovided child care services. Therefore, we would expect $\beta<0$ for college-educated mothers when basic childcare is the dependent variable.

\subsection{Econometric Challenges}

The estimation of equation (1) poses a major challenge. Because immigrants are not randomly distributed across the United States but, rather, choose to locate in thriving states where mothers (and, even more so, college-educated mothers) are more likely to be at work and request child care services, low-skilled immigration is likely to be endogenous to the time spent on child care. Ordinary least squares (OLS) estimates are thus likely to suffer of a downward bias, particularly among college-educated women for whom the opportunity cost of their time rises during an economic boom. To deal with this problem, we instrument for the location of immigrants using information on the historical distribution of immigrants of a given country. Specifically, following Furtado and Hock (2010) and inspired in other studies in the literature that rely on the propensity of new immigrants to locate in areas where they have country networks as a justification for their choice of instruments (e.g. Bartel 1989, 
Massey et al. 1993, Munshi 2003, Card 2001, Cortés 2008, Cortés and Tessada 2010, among many others), we construct the following instrument:

$$
\sum_{c} \frac{\text { immigrants }_{c s 1960}}{\text { immigrants }_{c 1960}} * \Delta \text { Lowskill immigrants }{ }_{c t}
$$

where the sub-index $c$ stands for immigrants' country of origin in the 1960 Census. The share $\frac{\text { immigrants }_{c s 1960}}{\text { immigrants }_{c 1960}}$ represents the fraction of all immigrants from country $c$ living in state $s$ in 1960. The second term ( $\Delta$ Lowskill immigrants ${ }_{c t}$ ) represents the net change in the number of low-skilled immigrants in the labor force from country c between 1960 and time $t$, where $t$ refers to 1970, 1990 and 2000 and low-skilled immigrants are those with at most a high school education. Both terms are constructed using Census data. ${ }^{14}$ The instrument is then merged to the ATHUS data by state and decade. In particular, the instrument constructed using information from the 1970 Census is merged to the 1975-76 AHTUS time use data ("1970"), the IV constructed using information from the 1990 Census is merged to the 1992-94 AHTUS (“1990”), and the IV constructed using information from the 2000 Census is merged to the 2003 AHTUS (“2000”). ${ }^{15}$

For the above to be a valid instrument, it needs to be related to mothers' child care patterns only through the allocation of low-skilled immigrants across states. Note that the empirical analysis already includes state and time dummies. Therefore, we already control for state specific characteristics and for overall economy-wide trends over the time period under consideration. Yet, as noted by Cortés (2008) and Furtado and Hock (2010), it still has to be the case that: (a) the initial distribution of immigrants is uncorrelated with differential changes in relative economic conditions affecting the demand for child care services states 10 to 40 years later, and (b) differential economic changes among states should not affect the overall inflow of low-skilled immigrants to the United States. To increase the likelihood that these conditions are met, we include some additional controls.

First, we address the possibility that regions where immigrants migrated to in 1960 were economically booming regions that would have experienced an increased in the demand for market child care services by college-educated mothers (perhaps as they become more likely to join the labor market ranks) regardless of immigrant concentration. To alleviate this

\footnotetext{
${ }^{14}$ We obtain similar results when we use the stock of low-skilled immigrants, as opposed to the flow of lowskilled immigrants, in the construction of the instrument (results available upon request).

${ }^{15}$ While there is an inevitable lag between the Censuses and the AHTUS surveys, it should not significantly impact our estimates given the small changes in the share of low-skilled immigrants at the state level within a 2 to 6 year period.
} 
concern, in an alternative specification (what we will refer to as specification (2) in what follows), we also include information on two variables intended to reflect an economically booming region: (a) the share of working age women with a college degree in each state in 1960, and (b) the share of working age women with at least a college degree who participate in the labor force in each state in $1960 .{ }^{16}$ Both controls are also interacted with time dummies to account for differences in initial conditions at the state-level potentially correlated over time.

Additionally, we foresee the possibility that our instrument could be capturing labor demand shocks to industries that have been persistently important in those states attracting most immigrants in our sample. It is worth noting, however, that much of the increase in the share of low-skilled immigrants in the 1960s resulted from the implementation of guest worker programs, such as the Bracero program spanning from 1942 to 1964, which recruited only male workers less likely to be employed in child care services (Gonzalez 2006, Gonzalez and Fernandez 2003). Nevertheless, in the alternative specification, we also include information on the following three variables, constructed for each state using 1960 data and intended to capture labor demand shocks to industries in the states where immigrants reside: (a) the share of the labor force employed in the high-skilled service sector, (b) the share of the labor force employed in the low-skilled service sector, and (c) average hourly wages for people with at least a college degree. ${ }^{17}$ All three regressors are also interacted with the time dummies to, again, capture state-level differences in initial conditions that are correlated over time.

Lastly, previous research has indicated that early access to the pill drove trends in fertility and female supply. We thus create a dummy variable indicative of whether the state had legalized the pill by 1960. According to Bailey (2006), only two states had done so, i.e. Alaska and Arkansas. We interact that dummy with the time dummies as well.

A final concern worth discussing is whether natives are responding to the location choices made by immigrants and migrating internally to regions where they do not compete with immigrants. Note, however, that even if that is the case, they are most likely less educated natives fearing labor market competition, not the college-educated mothers we are primarily focusing on. Furthermore, if labor mobility dissipates the effects of immigration

\footnotetext{
${ }^{16}$ Mulligan and Rubinstein (2008) note that increases in the return to skill have differentially induced highskilled women to enter the labor force and one factor predicting regional differences in rising returns to skill is the initial share of college-educated individuals.

${ }^{17}$ Controlling for the share of the labor force employed in the service sector also helps address the fact that differences in that sector are important drivers of regional differences in the demand for female labor (Olivetti and Petrongolo 2008).
} 
flows, our estimates should work as lower bound estimates of the total impact of low-skilled immigration on the time dedicated by college-educated mothers to various types of child care.

\section{Findings}

Table 3 shows the OLS and IV results from estimating equation (1) for our main sample of college-educated non-Hispanic mothers of non-school age children using the share of low-skilled immigrants as our key regressor. We present two different OLS specifications. The first specification in Column [1] coincides with equation (1), whereas the second specification in Column [2] adds the state-time controls discussed in the previous section. These include: the share of working-age women with college in each state in 1960, the share of working-age women with at least a college degree who participate in the labor force in each state in 1960, the share of the labor force employed in the high-skilled service sector, the share of the labor force employed in the low-skilled service sector and average hourly wages for people with at least a college degree. All these regressors are also interacted with survey fixed-effects for the 1970s, 1990s, and 2000s decades.

Differences in the coefficients between the first and second OLS specifications are minimal. The same is true for the IV specifications with and without aggregate controls. Therefore, column [3] displays the results of estimating specification [2] using IV methods. The bottom rows in Table 3 display the first-stage results. The coefficient on the IV is positive and highly significant at the 1 percent level. In particular, it indicates that an additional ten thousand low-skilled immigrants in the labor force from country $c$ in state $s$ between 1960 and time $t$, increases the share of low-skilled immigrants in state $s$ at time t by about 7 percent. ${ }^{18}$ The second to last row in Table 3 shows that the instrument is a very good predictor of the share of low-skilled immigrants. The associated F-statistic is 21.41, which allows us to reject the null of a weak instrument (see Stock and Yogo, 2005).

The estimates in Table 3 show that low-skilled immigration appears to have a differential impact on the child care provision of college-educated mothers of non-school age children depending on the type of child care at hand. In particular, in line with the predictions of the model, the 2 percentage point increase in the share of low-skilled immigrants taking place between the 1970s and 2000 lowered the time allocated by collegeeducated mothers to basic child care by a little bit more than half an hour per week. In contrast, the same increase in the share of low-skilled immigrants raised the time allocated to educational and recreational child care by college-educated mothers by a quarter of an hour -

\footnotetext{
${ }^{18}$ See Table B3 in the appendix for descriptive statistics of the IV and immigrant shares over this period.
} 
although this effect is only marginally statistically significant at the 10 percent level. IV estimates are larger than OLS estimates in all specifications, suggesting that OLS estimates may be biased downwards as a result of immigrants tending to locate in regions experiencing a higher growth rate, and college-educated mothers in those regions reducing the time allocated to child care. The decrease in basic child care and the increase in educational and recreational child care that followed the rise in low-skilled immigration had a net effect of reducing child care time by about 21 minutes per week. ${ }^{19}$

Similar results are obtained using the share of low-skilled female immigrants as our key regressor. As displayed in Table 4, the 0.8 percentage point increase in the share of lowskilled female immigrants taking place between the 1970s and the 2000s lowered the time allocated to basic child care by college-educated mothers of non-school age children by 0.68 hours/week (about 40 minutes/week), while it increased their time spent on educational and recreational child care activities by 0.3 hours/week (or 17 minutes/week) -although, once more, this effect is only marginally statistically significant at the 10 percent level, as in Table 3. The last rows in Table 4 show that the instrument is a very good predictor of the share of low-skilled female immigrants as well. The associated coefficient is, again, positive and statistically significant and the F-statistic is 11.92. Given the similarity of the results, we will follow previous U.S. studies in this literature (such as Cortés and Tessada 2010 or Furtado and Hock 2010), and use the share of low-skilled immigrants for the remainder of the analysis.

A second prediction from the model is that low-skilled immigration had a differential impact on the child care provision of mothers of non-school age children depending on their educational attainment. Table 5 shows the OLS and IV results from estimating equation (1) for our main sample of non-college educated non-Hispanic mothers of non-school age children. The model specifications are the same ones from Table 3. The 1970-2000 increase in the share of low-skilled immigrants raised the time devoted to basic child care activities by 0.75 hours/week (or 45 minutes/week). Additionally, it had no statistically significant impact on the educational or recreational child care. Note, however, that due to the marginally significant impact of low-skilled immigration on the time dedicated by more educated mothers to educational and recreational child care, low-skilled immigration did not have a

\footnotetext{
19 At this juncture in the paper, it is worth noting that these results are not driven by the impact of low-skilled immigration on the fertility of college-educated native mothers. Specifically, college-educated native mothers between 21-55 years of age in the AHTUS do not appear to be statistically more likely to have 0-5 year old children in the household when residing in states with a higher share of low-skilled immigrants.
} 
statistically different impact on the time dedicated by more educated as opposed to less educated mothers to that category of child care.

Although we do not model labor market displacement effects in our simple time use model, this finding suggests that immigration may have exerted a downwards pressure on the employment of less-educated mothers through greater competition in the labor market. This hypothesis is, in fact, confirmed by Cortés and Tessada (2010), who find that low-skilled immigration during 1980-2000 lowered the labor force participation of women with a highschool education or less in the United States. ${ }^{20}$ Under such circumstances, less educated mothers may have chosen to stay at home and take care of their own children. The figures in the bottom rows of Tables 3 through 5 examine that possibility. While the estimated coefficients on the labor market participation and hours worked by mothers with at least some college education are positive, we do not find a statistical significant impact of low-skilled immigration on the time dedicated to market work by that group of mothers. Unlike Cortés and Tessada (2010), we do not restrict our sample to women with advanced degrees, such as Masters and Ph.D.'s. Rather, it includes women with more than a high school education, for whom low-skilled immigration may not have had equally strong complementary impacts. Interestingly, however, low-skilled immigration appears to have marginally reduced the employment likelihood of less educated native mothers of non-school age children. Specifically, the 2 percent increase in the share of low-skilled immigrants taking place between the 1970s and the year 2000 resulted in a 4.6 percentage-point lower likelihood of engaging in market work. Additionally, the 1970-2000 increase in the share of low-skilled immigrants also raised the time allocated by these less educated mothers to home production considerably by 37 minutes minutes/week.

We also perform some robustness checks to assess if these results are unique to college-educated mothers of young children. We first look at college-educated mothers of older children. Column 3 of Table 6 shows that the 2 percentage point increase in the share of low-skilled immigrants of the period 1970-2000 had no statistically significant impact on the overall time allocated to child care by this group of mothers. When distinguishing by the type of child care provided, we find that, unlike mothers of non-school age children, collegeeducated mothers of school-age children did not significantly change their provision of basic child care following the increase in low-skilled immigration. This finding is not surprising since mothers of older children dedicate significantly less time to basic child care than their

\footnotetext{
${ }^{20}$ Likewise, focusing on Spain, Farré et al. (2011) find that the effect of low-skilled immigration in increasing female labor supply dies out as less educated native women are added to the sample.
} 
counterparts with non-school age children. It is, however, interesting to find that low-skilled immigration allowed college-educated mothers of school-age children to slightly reduce, albeit by only 5 minutes/week, the time invested in recreational/educational child care. In 2000, approximately 60 percent of the time invested by mothers of these school-age children in recreational/educational childcare went to supervising the children while they played or worked on homework. Hence, low-skilled immigration may have allowed for a small reduction in the provision of more age-appropriate child care, as is the case with child supervision after they arrive from school.

We also re-estimate our models using an analogous sample of fathers. Because there are many more college-educated fathers married to less educated mothers (especially in the earlier years) than college-educated mothers married to less educated fathers, we divide the father sample by the educational attainment of the wife. This reduces the number of years available for our analysis, as information on the spouse's educational attainment is only available in the 1975-76 and the 2003 surveys. ${ }^{21}$ Table 6 displays the results. As predicted by the theory, the estimated coefficients bear a negative sign; however, they are not statistically different from zero. Hence, the increases in low-skilled immigration appear to have led to reductions in the provision of basic and total child care time that are specific to high-skilled mothers of non-school age children.

\section{Summary and Conclusions}

Previous work has shown that low-skilled immigration to the United States allowed for a substantial reduction in the price of locally traded goods and services in the United States (Cortés 2008) and, more specifically, on the cost of market-provided child care, food and housekeeping services in large metropolitan areas (Furtado and Hock 2009). Based on those findings, Cortés and Tessada (2010) show that low-skilled immigration to the United States led to increases in hours worked conditional on being employed among native collegeeducated women in the United States. In turn, Furtado and Hock (2010) show how lowskilled immigration reduced the work-fertility tradeoff faced by educated urban American women.

We go one step further and examine how low-skilled immigration, via its impact on the cost of household services, may have impacted the allocation of time to child care of college-educated mothers in the United States. Using historical time use data and an

\footnotetext{
${ }^{21}$ The 1992-94 did not ask about the marital status of the respondent. The 1994-95 supplement asked whether respondents were in couples, but did not asked any information on the partner's educational level.
} 
instrumental variables approach that accounts for the endogenous location of low-skilled immigration, we find that low-skilled immigration to the United States had a differential impact on the child care provision of mothers depending on their educational attainment and the type of child care. In particular, low-skilled immigration to the United States has contributed to substantial reductions in the time allocated to basic child care by collegeeducated mothers of non-school age children. However, these mothers have not reduced the time allocated to more stimulating educational and recreational activities with their children. These findings underscore the opportunity costs faced by high-skilled mothers of young children.

In addition to informing about low-skilled immigration impacts beyond employment, wages and fertility, learning about the impact that increases in low-skilled immigration might have had on the time allocated by parents to various types of child care is important since some types of child care can prove particularly important for the child's posterior intellectual and social development. This is a crucial policy question with important consequences for the intergenerational transmission of economic status, and may help to better understand the parent-child correlations extensively documented in the literature (see Black and Devereux (2011) for a literature review on Intergenerational Mobility). Our work highlights the need for further research on the determinants of the time mothers spend on child care activities and how the latter impacts children outcomes depending on mothers' educational attainment. 


\section{References}

Aguiar, Mark and Erik Hurst. 2007. "Measuring Trends in Leisure: The Allocation of Time Over Five Decades” Quarterly Journal of Economics, 122: 969-1006.

Aydemir, Abdurrahman and George Borjas. 2006. “Attenuation Bias in Estimating the Wage Impact of Immigration”, Working Paper, Harvard University.

Bailey, Martha J. 2006. "More Power to the Pill: The Impact of Contraceptive Freedom on Women's Life Cycle Labor Supply” The Quarterly Journal of Economics, 121(1): 289-320.

Baker, Michael, Jonathan Gruber and Kevin Milligan. 2006. "Universal Childcare, Maternal Labor Supply, and Family Well-Being”, Journal of Political Economy, 116(4): 709745.

Bartel, Ann P. 1989. "Where Do the New U.S. Immigrants Live?” Journal of Labor Economics, 7(5): 371-91.

Becker, Gary. 1965. “A Theory of the Allocation of Time” Economic Journal, 75: 493-517.

Bianchi, Suzanne M., John P. Robinson, and Melissa A. Milkie. 2006. Changing Rhythms of American Family Life. New York: Russel Sage Foundation.

Black, Sandra E. and Paul J. Devereux. 2011. "Recent Developments in Intergenerational Mobility” Handbook of Labor Economics, Elsevier.

Blau, David M. 2003. "The Supply of Child Care Labor” Journal of Labor Economics, 11(2): 324-347.

Blau, David M. and Janet Currie. 2004. “Preschool, Day Care, and Afterschool Care: Who’s Minding the Kids.” NBER Working Paper No. 10670.

Blau, David M. and Alison P. Hagy. 1998. “The Demand for Quality in Child Care.” Journal of Political Economy, 106(1): 104-146.

Blau, David M. and H. Naci Mocan. 2002. “The Supply of Quality in Child Care Centers.” Review of Economics and Statistics, 84(3): 483-496.

Borjas, George J. 2003. “The Labor Demand Curve is Downward Sloping: Reexamining the Impact of Immigration on the Labor Market." Quarterly Journal of Economics 118(4): 1335-1374.

Breierova, Lucia, and Esther Duflo. 2004. "The impact of education on fertility and child mortality: Do fathers really matter less than mothers?” NBER Working Paper No. 10513, National Bureau of Economic Research.

Budig, M. J., and Nancy Folbre. 2004. Activity, Proximity, or Responsibility? Mearsuring Parental Childcare Time. New York: Routledge, In Family Time: The Social Organization of Care, Folbre and Bittman (eds.). 
Burda, Michael, Dan Hamermesh, and Philippe Weil. 2008. "The Distribution of Total Work in the EU and U.S.” in Tito Boeri, Michael Burda, Francis Kramarz (eds.): Working Hours and Job Sharing in the EU and USA: Are Americans Crazy? Are Europeans Lazy?, Oxford University Press.

Card, David. 2001. "Immigrant Inflows, Native Outflows and the Local Labor Market Impacts of Higher Immigration” Journal of Labor Economics, 19 (January).

Connelly, Rachel. 1992. 'The effect of child care costs on married women's labor force participation.’ Review of Economics and Statistics, 74: 83-90.

Cortés, Patricia. 2008. “The Effect of Low-Skilled Immigration on U.S. Prices: Evidence from CPI Data” Journal of Political Economy, 116 (3): 381-422.

Cortés, Patricia and José Tessada. 2010. "Low-Skilled Immigration and the Labor Supply of Highly Skilled Women”, forthcoming in the American Economic Journal: Applied Economics.

Del Boca, Daniela, Christopher Flinn and Matthew Wiswall. 2010. "Household Choices and Child Development,” IZA Discussion Papers 5155, Institute for the Study of Labor (IZA).

Farré, Lídia, Libertad Gonzalez, and Francesc Ortega. 2011. "Immigration, Family Responsibilities and the Labor Supply of Skilled Native Women.” The B.E Journal of Economic Analysis \& Policy, 11(1), Article 34.

Fisher, Kimberly. 2005. "Examining the dynamics of childcare using the American TimeUse Survey and USA heritage time use data sets." Paper presented at the 2005 International Association for Time Use Research Conference, Halifax, Canada.

Fisher, Kimberly, Muriel Egerton, Jonathan I. Gershuny and John P. Robinson. 2007. "Gender Convergence in the American Heritage Time Use Study (AHTUS)" Social Indicators Research, 82(1): 1-33.

Folbre, Nancy and Michael Bittman. 2004. Family Time: The Social Organization of Care. New York: Routledge.

Folbre, Nancy and Jayoung Yoon. 2007. "What is Child Care? Lessons from Time-Use Surveys of Major English-Speaker Countries" Review of Economics of the Household 5(3): 223-48.

Furtado, Delia and Heinrich Hock. 2010. "Low Skilled Immigration and Work-Fertility Tradeoffs among High Skilled US Natives” American Economic Review, 100(2): 22428.

Furtado, Delia and Heinrich Hock. 2009. "Female Work and Fertility in the United States: Effects of Low-Skilled Immigrant Labor“, SSRN Working Paper Series.

Gelbach, Jonah. 2002. "Public Schooling for Young Children and Maternal Labor Supply" American Economic Review, 92 (March): 307-22. 
Giménez-Nadal, José Ignacio and Almudena Sevilla. 2012. “Trends in Time Allocation: A Cross-Country Analysis", The European Economic Review, DOI: 10.1016/j.euroecorev.2012.02.011.

Gonzalez, Gilbert G. 2006. Guest Workers or Colonized Labor? Mexican Labor Migration to the United States. Boulder, CO: Paradigm Publishers.

Gonzalez, Gilbert G., and Raúl A. Fernández. 2003. A Century of Chicano History: Empire, Nations, and Migration. New York: Routledge.

Gronau, Reuben. 1977. "Leisure, Home Production, and Work-The Theory of the Allocation of Time Revisited” Journal of Political Economy, 85(6): 1099-1123.

Guryan, Jonathan, Erik Hurst, and Melissa Kearney. 2008. "Parental Education and Parental Time with Children” Journal of Economic Perspectives, 22(3): 23-46.

Helburn, Suzanne W., and Carollee Howes. 1996. "Child Care Cost and Quality.” The Future of Children, 6(2): 62-82.

Hill, C. Russell and Frank P. Stafford. 1974. "Allocation of Time to Preschool Children and Educational Opportunity” The Journal of Human Resources, 9(3): 323-41.

Juster, F. Thomas. 1985. “The Validity and Quality of Time Use Estimates Obtained from Recall Diaries” in F. Thomas Juster and Frank P. Stafford, eds. Time, Goods, and Well-Being, pp. 63-91. Ann Arbor: University of Michigan Press.

Havnes, Tarjei and Mogstad, Magne, 2011. "No Child Left Behind: Subsidized Child Care and Children's Long-Run Outcomes,” American Economic Journal: Economic Policy, American Economic Association, vol. 3(2), 97-129.

Hotz, V. Joseph, and M. Rebecca Kilburn. 1991. "The Demand for Child Care and Child Care Costs: Should We Ignore Families with Non-Working Mothers?” Discussion Paper 91-11. Population Research Center, University of Chicago.

Kimmel, Jean and Rachel Connelly. 2007. "Mothers' Time Choices: Caregiving, Leisure, Home Production, and Paid Work” Journal of Human Resources, 42(3): 643-81.

Krueger, Alan, Daniel Kahneman, David Schkade, Norbert Schwarz and Arthur Stone. 2009. "National Time Accounting: The Currency of Life", forthcoming in National Time Accounting and Subjective Well-Being.

Leibowitz, Arleen, 1974. "Home Investments in Children“, Journal of Political Economy, Vol. 82, No. 2, Part 2: Marriage, Family Human Capital, and Fertility, 111-131

Massey, Douglas S., Joaquin Arango, Graeme Hugo, Ali Kouaouci, Adela Pellegrino and J. Edward Taylor. 1993. "Theories of International Migration: A Review and Appraisal” Population and Development Review, 19: 431-466.

Mulligan, Casey B. and Yona Rubinstein. 2008. “Selection, Investment, and Women’s Relative Wages over Time” Quarterly Journal of Economics, 123(3): 1061-110. 
Munshi, Kaivan. 2003. "Networks in the Modern Economy: Mexican Migrants in the United States Labor Market” Quarterly Journal of Economics, 118: 549-597.

Olivetti, Claudia and Barbara Petrongolo. 2008. "Unequal Pay or Unequal Employment? A Cross-Country Analysis of Gender Gaps” Journal of Labor Economics, 26(4): 621654.

Ramey, Garey and Valerie A. Ramey. 2010. “The Rug Rat Race”, Brookings Papers on Economic Activity, 129-176

Robinson, John P. and Geoffrey Godbey. 1999. Time for Life: The Surprising Ways Americans Use Their Time. University Park, PA: Pennsylvania State University.

Robinson, John P. and F.T. Juster. 1985. "The Validity and Reliability of Diaries Versus Alternative Time Use Measures”, in F.T. Stafford and F.P. Stafford (eds) Time, Goods, and Well-Being, pp. 33-62. Survey Research Centre, University of Michigan.

Sayer, Liana C., Anne H. Gauthier, and Frank F. Furstenberg. 2004. "Educational Differences in Parents' Time with Children: Cross-National Variations” Journal of Marriage and Family, 66(5): 1152-69.

Schultz, Paul. 2002. "Why governments should invest more to educate girls." World Development, 30(2), 207-225.

Stock, James and Motohiro Yogo (2005). "Testing for Weak Instruments in Linear IV Regression” in D.W.K. Andrews and J.H. Stock, eds., Identification and Inference for Econometric Models: Essays in Honor of Thomas Rothenberg, Cambridge: Cambridge University Press, 80-105. 
Table 1

Time Use Trends of Mothers with Children Ages 0-5 by Educational Attaintment

\begin{tabular}{|c|c|c|c|}
\hline & All & $\begin{array}{l}\text { More than a High } \\
\text { School Degree }\end{array}$ & $\begin{array}{l}\text { At most a High } \\
\text { School Degree }\end{array}$ \\
\hline \multicolumn{4}{|c|}{ Child Care Time } \\
\hline \multirow[t]{2}{*}{1970} & 10.046 & 11.686 & 9.411 \\
\hline & $(0.727)$ & $(1.423)$ & $(0.794)$ \\
\hline \multirow[t]{2}{*}{1990} & 11.109 & 11.7 & 10.31 \\
\hline & $(0.660)$ & $(0.900)$ & $(0.939)$ \\
\hline \multirow[t]{3}{*}{2000} & 18.694 & 19.711 & 16.534 \\
\hline & $(0.285)$ & $(0.357)$ & $(0.467)$ \\
\hline & \multicolumn{3}{|c|}{ Basic Child Care Time } \\
\hline \multirow[t]{2}{*}{1970} & 8.433 & 10.06 & 7.802 \\
\hline & $(0.568)$ & $(1.120)$ & $(0.613)$ \\
\hline \multirow[t]{2}{*}{1990} & 8.166 & 8.426 & 7.813 \\
\hline & $(0.515)$ & $(0.708)$ & $(0.725)$ \\
\hline \multirow[t]{3}{*}{2000} & 12.168 & 12.691 & 11.059 \\
\hline & $(0.222)$ & $(0.281)$ & $(0.360)$ \\
\hline & \multicolumn{3}{|c|}{ Educational/Recreational Child Care Time } \\
\hline \multirow[t]{2}{*}{1970} & 1.613 & 1.626 & 1.608 \\
\hline & $(0.416)$ & $(0.821)$ & $(0.447)$ \\
\hline \multirow[t]{2}{*}{1990} & 2.943 & 3.273 & 2.496 \\
\hline & $(0.377)$ & $(0.519)$ & $(0.528)$ \\
\hline \multirow[t]{3}{*}{2000} & 6.526 & 7.02 & 5.476 \\
\hline & $(0.163)$ & $(0.206)$ & $(0.262)$ \\
\hline & & Tarket Work Time & \\
\hline \multirow[t]{2}{*}{1970} & 0.28 & 0.342 & 0.256 \\
\hline & $(0.024)$ & $(0.045)$ & $(0.027)$ \\
\hline \multirow[t]{2}{*}{1990} & 0.395 & 0.45 & 0.319 \\
\hline & $(0.022)$ & $(0.029)$ & $(0.032)$ \\
\hline \multirow[t]{3}{*}{2000} & 0.443 & 0.469 & 0.388 \\
\hline & $(0.009)$ & $(0.011)$ & $(0.016)$ \\
\hline & & Market Work Tim & \\
\hline \multirow[t]{2}{*}{1970} & 13.459 & 17.463 & 11.907 \\
\hline & (1.377) & (2.663) & (1.551) \\
\hline \multirow[t]{2}{*}{1990} & 20.62 & 23.515 & 16.698 \\
\hline & $(1.250)$ & (1.683) & (1.833) \\
\hline \multirow[t]{3}{*}{2000} & 21.171 & 22.181 & 19.025 \\
\hline & $(0.539)$ & $(0.668)$ & $(0.911)$ \\
\hline & & Housework Time & \\
\hline \multirow[t]{2}{*}{1970} & 30.884 & 31.233 & 30.749 \\
\hline & $(0.909)$ & (1.668) & (1.125) \\
\hline \multirow[t]{2}{*}{1990} & 25.896 & 25.282 & 26.728 \\
\hline & $(0.825)$ & $(1.054)$ & (1.330) \\
\hline \multirow[t]{3}{*}{2000} & 24.367 & 24.422 & 24.25 \\
\hline & $(0.356)$ & $(0.418)$ & $(0.661)$ \\
\hline & & Residual Time & \\
\hline \multirow[t]{2}{*}{1970} & 113.611 & 107.618 & 115.934 \\
\hline & $(1.210)$ & $(2.210)$ & (1.479) \\
\hline 1990 & 110.375 & 107.504 & 114.264 \\
\hline & $(1.098)$ & $(1.397)$ & $(1.748)$ \\
\hline 2000 & 103.564 & 101.476 & 107.996 \\
\hline & $(0.474)$ & $(0.554)$ & $(0.869)$ \\
\hline Observations & 3740 & 2362 & 1378 \\
\hline
\end{tabular}

Notes: Sample is women between 21 and 55 years old with at least one child between 0 and 5 years old and who have a complete 24-hour diary. Child care measures are in hours per week. Standard errors are in parentheses. 
Table 2

Trend in the Share of Low-Skilled Immigrants

\begin{tabular}{|c|c|c|c|c|c|c|}
\hline \multirow{2}{*}{$\begin{array}{l}\text { Shares: } \\
\text { Decades: }\end{array}$} & \multicolumn{3}{|c|}{ Low Skilled Immigrant Share } & \multicolumn{3}{|c|}{ Low Skilled Female Immigrant Share } \\
\hline & 1970s & 1990s & 2000s & 1970s & 1990s & 2000s \\
\hline U.S. & 0.042 & 0.048 & 0.061 & 0.017 & 0.02 & 0.025 \\
\hline Alabama & 0.004 & 0.006 & 0.015 & 0.002 & 0.003 & 0.006 \\
\hline Arizona & 0.041 & 0.058 & 0.103 & 0.016 & 0.023 & 0.036 \\
\hline Arkansas & 0.005 & 0.008 & 0.024 & 0.003 & 0.004 & 0.009 \\
\hline California & 0.078 & 0.157 & 0.186 & 0.03 & 0.06 & 0.073 \\
\hline Colorado & 0.021 & 0.026 & 0.057 & 0.009 & 0.011 & 0.021 \\
\hline Connecticut & 0.084 & 0.051 & 0.064 & 0.034 & 0.024 & 0.028 \\
\hline Florida & 0.068 & 0.087 & 0.112 & 0.028 & 0.038 & 0.049 \\
\hline Georgia & 0.005 & 0.016 & 0.049 & 0.002 & 0.007 & 0.016 \\
\hline Illinois & 0.056 & 0.051 & 0.071 & 0.02 & 0.02 & 0.028 \\
\hline Indiana & 0.015 & 0.009 & 0.02 & 0.007 & 0.004 & 0.007 \\
\hline Iowa & 0.01 & 0.007 & 0.016 & 0.004 & 0.004 & 0.006 \\
\hline Kentucky & 0.003 & 0.006 & 0.014 & 0.002 & 0.003 & 0.005 \\
\hline Louisiana & 0.012 & 0.013 & 0.017 & 0.006 & 0.006 & 0.007 \\
\hline Maine & 0.044 & 0.019 & 0.018 & 0.018 & 0.009 & 0.009 \\
\hline Maryland & 0.027 & 0.031 & 0.05 & 0.012 & 0.015 & 0.023 \\
\hline Massachusetts & 0.08 & 0.056 & 0.069 & 0.035 & 0.026 & 0.032 \\
\hline Michigan & 0.04 & 0.016 & 0.023 & 0.014 & 0.007 & 0.009 \\
\hline Minnesota & 0.019 & 0.009 & 0.021 & 0.009 & 0.005 & 0.009 \\
\hline Mississippi & 0.006 & 0.005 & 0.011 & 0.003 & 0.003 & 0.004 \\
\hline Missouri & 0.013 & 0.008 & 0.016 & 0.006 & 0.004 & 0.007 \\
\hline Nebraska & 0.013 & 0.01 & 0.027 & 0.006 & 0.005 & 0.01 \\
\hline New Jersey & 0.085 & 0.074 & 0.102 & 0.035 & 0.034 & 0.044 \\
\hline New York & 0.113 & 0.085 & 0.112 & 0.045 & 0.038 & 0.049 \\
\hline North Carolina & 0.005 & 0.011 & 0.041 & 0.002 & 0.004 & 0.013 \\
\hline Ohio & 0.028 & 0.011 & 0.014 & 0.011 & 0.006 & 0.006 \\
\hline Oregon & 0.029 & 0.031 & 0.062 & 0.012 & 0.012 & 0.023 \\
\hline Pennsylvania & 0.029 & 0.014 & 0.019 & 0.012 & 0.006 & 0.009 \\
\hline South Carolina & 0.006 & 0.009 & 0.022 & 0.002 & 0.005 & 0.008 \\
\hline Tennessee & 0.003 & 0.007 & 0.02 & 0.001 & 0.004 & 0.007 \\
\hline Texas & 0.031 & 0.073 & 0.105 & 0.011 & 0.026 & 0.037 \\
\hline Utah & 0.034 & $\ldots$ & 0.048 & 0.012 & $\ldots$ & 0.018 \\
\hline Virginia & 0.015 & 0.027 & 0.046 & 0.008 & 0.013 & 0.02 \\
\hline Washington & 0.046 & 0.039 & 0.066 & 0.02 & 0.017 & 0.028 \\
\hline West Virginia & 0.006 & 0.004 & 0.006 & 0.002 & 0.002 & 0.003 \\
\hline
\end{tabular}

Source: 1970, 1990 and 2000 Census data. Low-skilled immigrants are those with at most a high school degree. 
Table 3

Time Use of Mothers with More than a HS Degree and the Share of Low-Skilled Immigrants (Mothers with Children 0-5)

\begin{tabular}{|c|c|c|c|}
\hline & \multicolumn{2}{|c|}{ OLS } & \multirow{2}{*}{$\begin{array}{l}\text { IV } \\
{[3]}\end{array}$} \\
\hline & [1] & [2] & \\
\hline Independent Variable: & \multicolumn{3}{|c|}{ Total Child Care Time } \\
\hline Low-skilled Immigrant Share & $\begin{array}{c}-15.707 * * * \\
(5.852)\end{array}$ & $\begin{array}{c}-15.706^{* * *} \\
(5.898)\end{array}$ & $\begin{array}{c}-17.795 * * * \\
(5.831)\end{array}$ \\
\hline Independent Variable: & \multicolumn{3}{|c|}{ Basic Child Care Time } \\
\hline Low-skilled Immigrant Share & $\begin{array}{c}-25.679 * * * \\
(3.579)\end{array}$ & $\begin{array}{c}-25.679 * * * \\
(3.603)\end{array}$ & $\begin{array}{c}-30.510 * * * \\
(3.780)\end{array}$ \\
\hline Independent Variable: & \multicolumn{3}{|c|}{ Educational/Recreational Child Care Time } \\
\hline Low-skilled Immigrant Share & $\begin{array}{l}9.972 * * \\
(4.082)\end{array}$ & $\begin{array}{l}9.972 * * \\
(4.110)\end{array}$ & $\begin{array}{l}12.715^{*} \\
(6.593)\end{array}$ \\
\hline Independent Variable: & \multicolumn{3}{|c|}{ p(Market Work Time) $>0$} \\
\hline Low-skilled Immigrant Share & $\begin{array}{c}0.179 \\
(0.150)\end{array}$ & $\begin{array}{c}0.179 \\
(0.151)\end{array}$ & $\begin{array}{c}0.339 \\
(0.228)\end{array}$ \\
\hline Independent Variable: & \multicolumn{3}{|c|}{ Market Work Time } \\
\hline Low-skilled Immigrant Share & $\begin{array}{c}6.937 \\
(6.422)\end{array}$ & $\begin{array}{c}6.936 \\
(6.472)\end{array}$ & $\begin{array}{c}7.06 \\
(6.817)\end{array}$ \\
\hline Independent Variable: & \multicolumn{3}{|c|}{ Housework Time } \\
\hline Low-skilled Immigrant Share & $\begin{array}{l}-9.701^{* * *} \\
(3.333)\end{array}$ & $\begin{array}{l}-9.701 * * * \\
(3.360)\end{array}$ & $\begin{array}{l}-6.645 \\
(6.037)\end{array}$ \\
\hline Independent Variable: & \multicolumn{3}{|c|}{ Residual Time } \\
\hline Low-skilled Immigrant Share & $\begin{array}{c}20.098^{* * *} \\
(7.550)\end{array}$ & $\begin{array}{c}20.098 * * * \\
(7.610)\end{array}$ & $\begin{array}{c}18.760 * \\
(10.547)\end{array}$ \\
\hline \multicolumn{4}{|l|}{ First-stage Results: } \\
\hline IV & & & $\begin{array}{l}4.02 \mathrm{e}-07 * * * \\
(8.68 \mathrm{e}-08)\end{array}$ \\
\hline $\begin{array}{l}\text { F-stat. } \\
\text { R-sq. }\end{array}$ & & & $\begin{array}{c}21.411 \\
0.963\end{array}$ \\
\hline $\mathrm{N}$ & 2362 & 2362 & 2362 \\
\hline
\end{tabular}

Notes: Low-skilled immigrants are those with at most a high school degree. Specification [1] coincides with equation (1) in the text. Specification [2] includes the additional aggregate state-time controls described in the text. Specification [3] is analogous to specifications [2], but is estimated using the IV described in the main text. Child care time is measured in hours per week. We allow the disturbance term to be correlated across individuals (and over time) in the same state. Standard errors are in parentheses. * denotes significance at the $10 \%$ level, ** at the $5 \%$ level and ${ }^{* * *}$ at the $1 \%$ level. 
Table 4

Time Use of Mothers with More than a HS Degree and the Share of Low-Skilled Female Immigrants (Mothers with Children 0-5)

\begin{tabular}{|c|c|c|c|}
\hline & \multicolumn{2}{|c|}{ OLS } & \multirow{2}{*}{$\begin{array}{l}\text { IV } \\
{[3]}\end{array}$} \\
\hline & [1] & [2] & \\
\hline Independent Variable: & \multicolumn{3}{|c|}{ Total Child Care Time } \\
\hline Low-skilled Immigrant Share & $\begin{array}{l}-33.579 * \\
(19.590)\end{array}$ & $\begin{array}{l}-33.577 * \\
(19.744)\end{array}$ & $\begin{array}{c}-49.017 * * * \\
(13.714)\end{array}$ \\
\hline Independent Variable: & \multicolumn{3}{|c|}{ Basic Child Care Time } \\
\hline Low-skilled Immigrant Share & $\begin{array}{c}-61.382 * * * \\
(12.342)\end{array}$ & $\begin{array}{c}-61.381^{* * *} \\
(12.439)\end{array}$ & $\begin{array}{c}-84.040 * * * \\
(14.639)\end{array}$ \\
\hline Independent Variable: & \multicolumn{3}{|c|}{ Educational/Recreational Child Care Time } \\
\hline Low-skilled Immigrant Share & $\begin{array}{c}27.803^{* * *} \\
(9.415)\end{array}$ & $\begin{array}{c}27.803^{* * *} \\
(9.490)\end{array}$ & $\begin{array}{l}35.023 * \\
(20.589)\end{array}$ \\
\hline Independent Variable: & \multicolumn{3}{|c|}{ p(Market Work Time) $>0$} \\
\hline Low-skilled Immigrant Share & $\begin{array}{c}0.341 \\
(0.381)\end{array}$ & $\begin{array}{c}0.341 \\
(0.384)\end{array}$ & $\begin{array}{c}0.935 \\
(0.673)\end{array}$ \\
\hline Independent Variable: & \multicolumn{3}{|c|}{ Market Work Time } \\
\hline Low-skilled Immigrant Share & $\begin{array}{c}17.853 \\
(15.515)\end{array}$ & $\begin{array}{c}17.85 \\
(15.636)\end{array}$ & $\begin{array}{c}19.447 \\
(18.595)\end{array}$ \\
\hline Independent Variable: & \multicolumn{3}{|c|}{ Housework Time } \\
\hline Low-skilled Immigrant Share & $\begin{array}{c}-22.912 * * * \\
(7.497)\end{array}$ & $\begin{array}{c}-22.912 * * * \\
(7.556)\end{array}$ & $\begin{array}{l}-18.302 \\
(15.451)\end{array}$ \\
\hline Independent Variable: & \multicolumn{3}{|c|}{ Residual Time } \\
\hline Low-skilled Immigrant Share & $\begin{array}{l}42.859 * \\
(23.049)\end{array}$ & $\begin{array}{l}42.859 * \\
(23.231)\end{array}$ & $\begin{array}{l}51.675^{* *} \\
(25.699)\end{array}$ \\
\hline \multicolumn{4}{|l|}{ First-stage Results: } \\
\hline IV & & & $\begin{array}{l}1.46 \mathrm{e}-07^{* * *} \\
(4.22 \mathrm{e}-08)\end{array}$ \\
\hline $\begin{array}{l}\text { F-stat. } \\
\text { R-sq. }\end{array}$ & & & $\begin{array}{c}11.923 \\
0.937\end{array}$ \\
\hline $\mathrm{N}$ & 2362 & 2362 & 2362 \\
\hline
\end{tabular}

Notes: Low-skilled immigrants are those with at most a high school degree. Specification [1] coincides with equation (1) in the text. Specification [2] includes the additional aggregate state-time controls described in the text. Specification [3] is analogous to specifications [2], but is estimated using the IV described in the main text. Child care time is measured in hours per week. We allow the disturbance term to be correlated across individuals (and over time) in the same state. Standard errors are in parentheses. * denotes significance at the $10 \%$ level, $* *$ at the $5 \%$ level and $* * *$ at the $1 \%$ level. 
Table 5

Time Use of Mothers with At Most a HS Degree and the Share of Low-Skilled Immigrants (Mothers with Children 0-5)

\begin{tabular}{|c|c|c|c|}
\hline & \multicolumn{2}{|c|}{ OLS } & \multirow{2}{*}{$\begin{array}{l}\text { IV } \\
{[3]} \\
\end{array}$} \\
\hline & [1] & [2] & \\
\hline Independent Variable: & \multicolumn{3}{|c|}{ Total Child Care Time } \\
\hline Low-skilled Immigrant Share & $\begin{array}{c}25.832 \\
(19.387)\end{array}$ & $\begin{array}{c}25.825 \\
(19.650)\end{array}$ & $\begin{array}{c}49.698 \\
(30.289)\end{array}$ \\
\hline Independent Variable: & \multicolumn{3}{|c|}{ Basic Child Care Time } \\
\hline Low-skilled Immigrant Share & $\begin{array}{c}31.588 * * * \\
(9.391)\end{array}$ & $\begin{array}{c}31.583^{* * *} \\
(9.518)\end{array}$ & $\begin{array}{l}37.539 * * * \\
(12.202)\end{array}$ \\
\hline Independent Variable: & \multicolumn{3}{|c|}{ Educational/Recreational Child Care Time } \\
\hline Low-skilled Immigrant Share & $\begin{array}{c}-5.756 \\
(10.913)\end{array}$ & $\begin{array}{c}-5.758 \\
(11.061)\end{array}$ & $\begin{array}{c}12.158 \\
(19.007)\end{array}$ \\
\hline Independent Variable: & \multicolumn{3}{|c|}{ p(Market Work Time) $>0$} \\
\hline Low-skilled Immigrant Share & $\begin{array}{c}-1.105^{* * *} \\
(0.301)\end{array}$ & $\begin{array}{c}-1.105^{* * *} \\
(0.305)\end{array}$ & $\begin{array}{l}-2.281^{*} \\
(1.340)\end{array}$ \\
\hline Independent Variable: & \multicolumn{3}{|c|}{$\begin{array}{l}\text { Market Work Time } \\
\end{array}$} \\
\hline Low-skilled Immigrant Share & $\begin{array}{l}-37.858 \\
(26.722)\end{array}$ & $\begin{array}{l}-37.853 \\
(27.083)\end{array}$ & $\begin{array}{l}-115.608 \\
(90.067)\end{array}$ \\
\hline Independent Variable: & \multicolumn{3}{|c|}{$\begin{array}{l}\text { Housework Time } \\
\end{array}$} \\
\hline Low-skilled Immigrant Share & $\begin{array}{c}23.852 * \\
(12.553)\end{array}$ & $\begin{array}{c}23.851^{*} \\
(12.723)\end{array}$ & $\begin{array}{l}30.577 * * \\
(13.866)\end{array}$ \\
\hline Independent Variable: & \multicolumn{3}{|c|}{ Residual Time } \\
\hline Low-skilled Immigrant Share & $\begin{array}{l}-17.569 \\
(16.312)\end{array}$ & $\begin{array}{l}-17.564 \\
(16.532)\end{array}$ & $\begin{array}{c}31.086 \\
(58.026)\end{array}$ \\
\hline \multicolumn{4}{|l|}{ First-stage Results: } \\
\hline IV & & & $\begin{array}{l}4.02 \mathrm{e}-07 * * * \\
(8.68 \mathrm{e}-08)\end{array}$ \\
\hline $\begin{array}{l}\text { F-stat. } \\
\text { R-sq. }\end{array}$ & & & $\begin{array}{c}12.006 \\
0.953\end{array}$ \\
\hline $\mathrm{N}$ & 1378 & 1378 & 1378 \\
\hline
\end{tabular}

Notes: Low-skilled immigrants are those with at most a high school degree. Specification [1] coincides with equation (1) in the text. Specification [2] includes the additional aggregate state-time controls described in the text. Specification [3] is analogous to specifications [2], but is estimated using the IV described in the main text. Child care time is measured in hours per week. We allow the disturbance term to be correlated across individuals (and over time) in the same state. Standard errors are in parentheses. * denotes significance at the $10 \%$ level, ** at the $5 \%$ level and $* * *$ at the $1 \%$ level. 
Table 6

Child Care Time and the Share of Low-Skilled Immigrants (Alternative Samples)

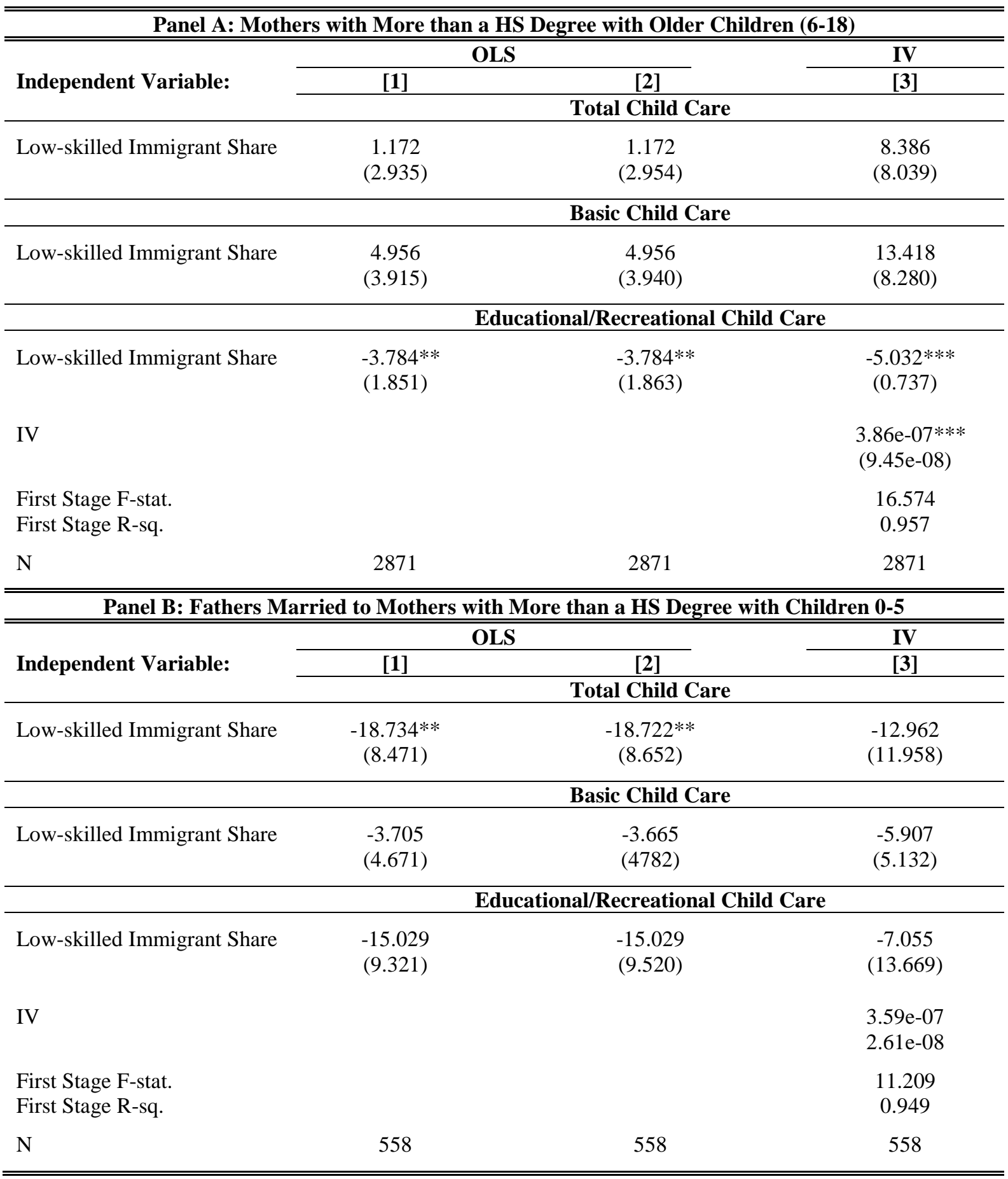

Notes: Low-skilled immigrants are those with at most a high school degree. Specification [1] coincides with equation (1) in the text. Specification [2] includes the additional aggregate state-time controls described in the text. Specification [3] is analogous to specifications [2], but is estimated using the IV described in the main text. Child care time is measured in hours per week. We allow the disturbance term to be correlated across individuals (and over time) in the same state. Standard errors are in parentheses. * denotes significance at the $10 \%$ level, ** at the $5 \%$ level and ***at the $1 \%$ level. 


\section{Appendix A: A Model of Child Care Provision}

A mother's maximization problem is given by:

$$
\begin{aligned}
& \max _{x, l, h} U(c)+V(l) \\
& s t: \\
& c=c(x, h) \\
& \lambda: p x=w(1-h-l) \\
& 1=L+l+h \\
& x, h, l, L \geq 0
\end{aligned}
$$

Case 1: Mother purchases child care services $\left(x^{*}>0\right)$ : Substituting the first constraint into the utility function yields the first order conditions:

$$
\begin{aligned}
& h: U_{c}{ }^{\prime} c_{h}{ }^{\prime}-\lambda w=0 \\
& x: U_{c}{ }^{\prime} c_{x}{ }^{\prime}-\lambda p=0 \\
& l: V_{l}{ }^{\prime}-\lambda w=0
\end{aligned}
$$

It is easy to see that dividing (A.2) by (A.3), we get Expression (3). Likewise, dividing (A.4) by (A.3) we get Expression (4), just as and dividing (A.4) by (A.2) we get expression (5):

$$
\begin{aligned}
& \frac{V_{l}^{\prime}}{U_{c}^{\prime} c_{X}^{\prime}}=\frac{w}{p} \\
& \frac{V_{l}^{\prime}}{U_{C}^{\prime} c_{h}^{\prime}}=1
\end{aligned}
$$

Equations (4) and (5) state that the marginal rate of substitution of leisure $(l)$ for either commercial child care $(x)$ or maternal child care time $(h)$ must be equal to the corresponding price ratio. In other words, the extra utility (via increases in well-cared for children $c$ ) from additional units of either commercial child care $(x)$ or maternal child care $(h)$ that is needed to compensate for a one-unit marginal reduction in the consumption of leisure $(l)$, should be equal to the marginal rate of exchange between leisure and commercial child care on the one hand, and leisure and maternal child care on the other hand.

Case 2: Mother does not purchase child care services $\left(x^{*}=0\right)$ : If this is the case, then Equation (A.3) does not hold with equality, but as follows:

$$
x: U_{c}{ }^{\prime} C_{x}{ }^{\prime}-\lambda p<0
$$

Dividing (A.3)' by (A.2) yields inequality (3)':

$$
\frac{c_{h}^{\prime}}{c_{x}^{\prime}}>\frac{w}{p}
$$

which shows that for low enough wages with respect to the price of commercial child care $(w / p)$, commercial child care becomes too expensive and it is optimal to minimize the use of commercial child care services and, instead, raise the provision of maternal child care. 


\section{Appendix B}

Table B1: AHTUS Description

\begin{tabular}{|c|c|c|c|}
\hline \multicolumn{4}{|c|}{ Study aims, target populations, and sample restrictions } \\
\hline Survey years & Organizing Aims and Considerations & Target Population & Sampling Restrictions \\
\hline 1965-1966 & $\begin{array}{l}\text { Comparability with the Multinational } \\
\text { Comparative Time-Budget project } \\
\text { collected in } 12 \text { countries }\end{array}$ & $\begin{array}{l}\text { The national working age population (19-64) of } \\
\text { the USA (excluding families where all members } \\
\text { worked as farmers) }\end{array}$ & $\begin{array}{l}\text { Only people aged } 19 \text { to } 64 \text { (with a few } \\
\text { older diarists), and one person per } \\
\text { household (Alaska, Hawaii, and some } \\
\text { smaller, rural states excluded) }\end{array}$ \\
\hline 1975-1976 & $\begin{array}{l}\text { Measure national accounts and changes in } \\
\text { time use over the year }\end{array}$ & The national adult population & $\begin{array}{l}\text { People aged } 18 \text { or older and one person } \\
\text { plus spouse if present per household }\end{array}$ \\
\hline 1985 & $\begin{array}{l}\text { Determined how people used their time and } \\
\text { to compare diaries collected by post- } \\
\text { out/post-back, phone, and face-to-face } \\
\text { interview }\end{array}$ & $\begin{array}{l}\text { The national population beyond secondary } \\
\text { school age not living in institutions }\end{array}$ & $\begin{array}{l}\text { People aged } 12 \text { or older living in private } \\
\text { households with phones (Alaska, Hawaii, } \\
\text { and some smaller, rural states excluded) }\end{array}$ \\
\hline 1992-1994 & The study measured time use and exposure & $\begin{array}{l}\text { The national population living in private } \\
\text { residences }\end{array}$ & $\begin{array}{l}1 \text { person of any age living in sampled } \\
\text { private households with phones (Alaska } \\
\text { and Hawaii excluded) }\end{array}$ \\
\hline 2003 & $\begin{array}{l}\text { The study follows a sub-sample of the CPS } \\
\text { for a } 9^{\text {th }} \text { wave to facilitate the study of } \\
\text { national accounts }\end{array}$ & $\begin{array}{l}\text { The national population not living in military } \\
\text { bases or institutions }\end{array}$ & $\begin{array}{l}1 \text { person aged } 15 \text { or older in the } \\
\text { household }\end{array}$ \\
\hline
\end{tabular}

\begin{tabular}{|c|c|c|c|}
\hline \multicolumn{4}{|c|}{ Relevant points in time from the sample designs } \\
\hline Survey years & Fieldwork Period & Sampling of Days of the Week & When Activities Were Recorded \\
\hline 1965-1966 & $\begin{array}{l}15 \text { November -15 December 1965; } \\
1 \text { January - } 18 \text { February 1966; } 7 \text { March - } 20 \\
\text { May, } 1966\end{array}$ & $\begin{array}{l}2 / 7 \text { ths of diaries were stamped for collection on } \\
\text { a weekend day; } 5 / 7 \text { ths were stamped for } \\
\text { collection on a weekday }\end{array}$ & $\begin{array}{l}\text { A two-stage tomorrow approach, diaries } \\
\text { left behind for completion on diary day }\end{array}$ \\
\hline $1975-1976$ & $\begin{array}{l}\text { Wave 1: } 9 \text { October } 1975 \text { - } 22 \text { November } \\
\text { 1975; Wave 2: } 6 \text { February } 1976 \text { - } 28 \text { March } \\
\text { 1976; Wave 3: } 2 \text { May } 1976 \text { - } 19 \text { July 1976; } \\
\text { Wave 4: } 4 \text { September } 1976 \text { - } 26 \text { October } \\
\text { 1976 }\end{array}$ & $\begin{array}{l}\text { The study aimed to collect one diary on a } \\
\text { Sunday, one on a Saturday, and two on different } \\
\text { weekdays from each sample member. }\end{array}$ & Diaries covered the previous 24 hour day \\
\hline 1985 & Whole year of 1985 & Mail-out after phone calls. & $\begin{array}{l}\text { Diaries to be completed on a specified } \\
\text { day in the subsequent week }\end{array}$ \\
\hline 1992-1994 & September 1992 - October 1994 & $\begin{array}{l}\text { Phone calls were attempted on all days of the } \\
\text { week. }\end{array}$ & Diaries covered the previous 24 hour day \\
\hline 2003 & Whole year of 2003 & $\begin{array}{l}\text { Half of diaries were collected on weekday, half } \\
\text { on weekend days. }\end{array}$ & Diaries covered the previous 24 hour day \\
\hline \multicolumn{4}{|c|}{ Sample designs and response rates } \\
\hline 1965-1966 & $\begin{array}{l}\text { Jackson, Michigan and surrounding } \\
\text { townships, and a national sample }\end{array}$ & $\begin{array}{l}\text { Jackson - random selection; National multi- } \\
\text { stage clustered area sampling of clusters } \\
\text { containing around } 4 \text { addresses; one individual } \\
\text { per household }\end{array}$ & $\begin{array}{l}82 \% \text { in Jackson; } 74 \% \text { in the national } \\
\text { sample }\end{array}$ \\
\hline 1975-1976 & Private households & $\begin{array}{l}\text { Stratified, clustered and probability selection } \\
\text { within strata. One individual was sampled per } \\
\text { household. Data was also collected from } \\
\text { spouses where present. }\end{array}$ & $\begin{array}{l}72 \% \text { in the first wave; } 44.9 \% \text { responded } \\
\text { to all four waves }\end{array}$ \\
\hline 1985 & $\begin{array}{l}\text { Adults } 18 \text { years or over, living in houses } \\
\text { with telephones in the contiguous United } \\
\text { States. }\end{array}$ & $\begin{array}{l}\text { Stratified and clustered, random-digit dialing, } \\
\text { with only private residences pursued for an } \\
\text { interview. Information on the household } \\
\text { collected by telephone. }\end{array}$ & $\begin{array}{l}55.2 \% \text { overall, } 51 \% \text { for mail back } \\
\text { sample }\end{array}$ \\
\hline 1992-1994 & $\begin{array}{l}\text { Potential phone numbers within lists of } \\
\text { area codes }\end{array}$ & $\begin{array}{l}\text { Random-digit dialing, only private residences } \\
\text { pursued for interview. The person who would } \\
\text { next have a birthday completed the diary. }\end{array}$ & $63 \%$ \\
\hline
\end{tabular}

Source: Fisher et al. (2007). 
Table B2

Log Median Wage in Child Care and the Share of Low-Skilled Immigrants

\begin{tabular}{lcc}
\hline \hline Independent Variable & OLS & IV \\
\hline Low-skilled Immigrant Share & -1.633 & $-3.668^{* * *}$ \\
& $(1.171)$ & $(1.312)$ \\
R-squared & 0.885 & \\
First-stage Regression Results & & 21.773 \\
IV & & $2.15 \mathrm{e}-07^{* * *}$ \\
& & $(4.67 \mathrm{e}-08)$ \\
First Stage F-stat. & & 21.773 \\
First Stage R-sq. & & 0.9827 \\
$\mathrm{~N}$ & 137 & 137 \\
\hline \hline
\end{tabular}

Notes: All regressions include state and Census region-year fixed effects. Low-skilled immigrants are those with at most a high school degree. Additionally, we control for the logarithm of mean total income of college-educated men of working-age to account for the selective migration among immigrants based on changing local conditions within the state over time. Robust standard errors are clustered at the state level and shown in parentheses. * denotes significance at the $10 \%$ level, ** at the $5 \%$ level and ***at the $1 \%$ level. 
Table B3

Means and Standard Deviations of Other Variables Included in the Analysis

\begin{tabular}{|c|c|c|c|}
\hline Variables & All Mothers & $\begin{array}{c}\text { More than a HS } \\
\text { Degree }\end{array}$ & $\begin{array}{c}\text { At most a HS } \\
\text { Degree }\end{array}$ \\
\hline \multirow[t]{2}{*}{ Age } & 32.706 & 33.663 & 31.065 \\
\hline & $(0.110)$ & $(0.127)$ & $(0.196)$ \\
\hline \multirow[t]{2}{*}{ White dummy } & 0.81 & 0.845 & 0.751 \\
\hline & $(0.006)$ & $(0.007)$ & $(0.012)$ \\
\hline \multirow[t]{2}{*}{ Number of adults } & 1.951 & 1.979 & 1.904 \\
\hline & $(0.010)$ & $(0.011)$ & $(0.019)$ \\
\hline \multirow[t]{2}{*}{ Number of children under 5} & 1.109 & 1.143 & 1.049 \\
\hline & $(0.012)$ & $(0.014)$ & $(0.020)$ \\
\hline \multirow[t]{2}{*}{ Age youngest child } & 2.307 & 2.242 & 2.42 \\
\hline & $(0.027)$ & $(0.035)$ & $(0.045)$ \\
\hline \multirow[t]{2}{*}{ Summer dummy } & 0.153 & 0.159 & 0.144 \\
\hline & $(0.006)$ & $(0.008)$ & $(0.009)$ \\
\hline \multirow[t]{2}{*}{ Weekday dummy } & 0.484 & 0.485 & 0.484 \\
\hline & $(0.008)$ & $(0.010)$ & $(0.013)$ \\
\hline \multirow[t]{2}{*}{ Low-skilled Immigrant Share } & .0572 & & \\
\hline & $(.048)$ & & \\
\hline \multirow[t]{2}{*}{ Low-skilled Female Immigrant Share } & .0231 & & \\
\hline & $(.0193)$ & & \\
\hline \multirow[t]{2}{*}{ IV } & $37,628.26$ & & \\
\hline & $(69,458.72)$ & & \\
\hline $\mathrm{N}$ & 3740 & 2362 & 1378 \\
\hline
\end{tabular}

Notes: Sample is women between 21 and 55 years old with at least one child between 0 and 5 years old and who have a complete 24-hour diary. Standard deviations are in parentheses. 